The nine seismic cross-sections obtained show that the general structure of the shelf is rather uniform. An example is shown in fig. 19.

The irregular topography of the inner shelf is associated with rather sharp magnetic anomalies, with amplitudes of up to several hundred gammas, and no subbottom reflectors have been detected. It is therefore interpreted as an ice-eroded basement (Vogt, 1970). Roughly $80 \mathrm{~km}$ from the shelf edge, the basement is concordantly covered by a thick sequence of sediments. The boundary follows approximately a line from $65^{\circ} 30 \mathrm{~N}, 35^{\circ} 20^{\prime} \mathrm{W}$ to $63^{\circ} 30^{\prime} \mathrm{N}, 39^{\circ} 45^{\prime} \mathrm{W}$ and is often located in a broad valley on the sea floor. The concordant sediments have a gentle dip of approximately 1:100 away from the shore. This dip may represent a primary slope. Upwards, the sediments are cut by an erosional unconformity. In places in the northern part of the area adjacent to the basement, the unconformity forms the sea floor. However, normally it is overlain by a 50-500 m thick sequence of sediments which often attain their greatest thickness near the edge of the shelf.

\title{
References
}

Denham, L. R. 1974: Offshore geology of northern West Greenland $\left(69^{\circ}\right.$ to $\left.75^{\circ} \mathrm{N}\right)$. Rapp. Gronlands geol. Unders. 63, 24 pp.

Matthews, D. J. 1939: Tables of the velocity of sound in pure water and sea water. Hydrogr. Dept., London 139, 70 pp.

Sommerhoff. G. 1973: Formenschatz und morphologische Gliederung des südostgrönländischen Shelfgebietes und Kontinentalabhanges. "Meteor" Forsch.-Ergebnisse C 15, 1-54.

Vogt, P. R. 1970: Magnetized basement outcrops on the south-east Greenland continental shelf. Nature, Lond. 226, 743-744.

Institute for Applied Geology, Technical University of Denmark, Building 204, 2800 Lyngby.

\section{Aeromagnetic investigations in East Greenland}

\section{Hans Christian Larsen}

During 1974, aeromagnetic profiling and mapping were carried out in two different parts of East Greenland (fig. 20). The most southerly area comprised the continental shelf between $63^{\circ} 30^{\prime}$ and $66^{\circ} \mathrm{N}$ (Angmagssalik district), while the northern area covered the sedimentary basin of late Palaeozoic and Mesozoic rocks forming the land surface between $70^{\circ}$ and $74^{\circ} \mathrm{N}$.

In addition to straight magnetic flights, low ground clearance flights were carried out over the land area between $70^{\circ}$ and $76^{\circ} \mathrm{N}$ for purpose of radiometric investigation 


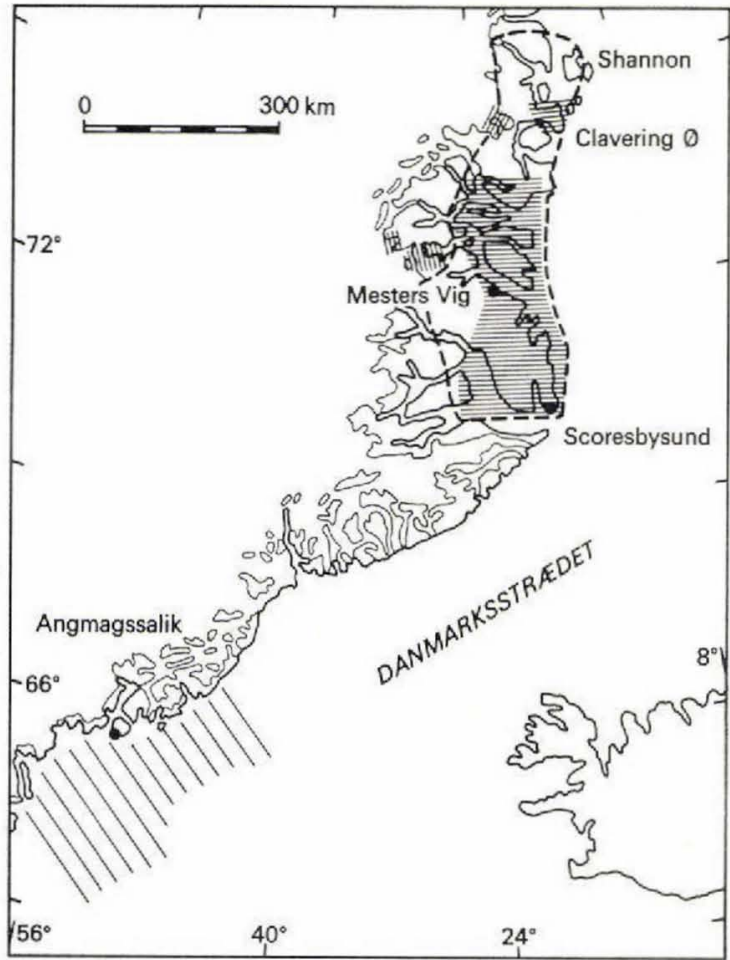

Fig. 20. Aeromagnetic investigations in East Greenland. The hachuring indicates the direction and intensity of straight magnetic flights. The broken line represents the limit of low ground clearance flights.

(see Nielsen \& Steenfelt, this report). About 32000 line $\mathrm{km}$ were surveyed, of which $20000 \mathrm{~km}$ were straight magnetic flights and $12000 \mathrm{~km}$ were low ground clearance flights.

\section{Instrumentation}

The survey was made with a proton magnetometer installed in a Britten-Norman Islander twin-engine aircraft chartered from Greenlandair Charter A/S. A fixed ground station proton magnetometer recorded the diurnal variations to allow later compensation for these variations. Both airborne data and ground data were recorded in digital form.

In the marine area Loran A navigation was employed, using two receivers. Visual navigation and photo navigation over the land areas was assisted by a continuously operating $35 \mathrm{~mm}$ camera.

\section{Preliminary results from the shelf area}

The survey of the shelf was made by aeromagnetic profiling. The profiles are almost perpendicular to the coastline, the line spacing varying from 10 to $40 \mathrm{~km}$. A flight altitude of 700 feet was generally maintained. 
A preliminary examination of the profiles indicates a shelf composed of basement with many strongly magnetised, more or less linear features, and a large sedimentary basin situated in the outer part of the shelf area. Depth-to-basement estimates for this basin range up to about $3 \mathrm{~km}$.

The delimitation of the boundaries of the sedimentary basin suggested by the present work is in perfect agreement with results obtained from a recent seismic survey (B. Larsen, this report). The prevalence of favourable magnetic anomalies in the investigated shelf area may allow the compilation of a rough depth-to-basement contour map.

\section{Preliminary results from the land area}

Magnetic surveying was carried out in the northern land area. The east-west profiles were spaced at 5 to $7.5 \mathrm{~km}$ intervals at a constant flight altitude of 6000 feet.

Compared to the Angmagssalik district, the land area contains fewer anomalies suitable for depth-to-basement estimates. Consequently, it may be more difficult to compile a depth-to-basement contour map of the land area, in spite of the greater density of data.

In the magnetic profiles a very abrupt rise of the magnetic field intensity is observed on passage from the Jameson Land sediments into the crystalline rocks of Liverpool Land. This north-south linear feature may indicate a fault boundary between the Jameson Land basin and the Liverpool Land crystalline complex. The fault, if any, must be pre-Triassic due to the occurrence of Triassic sediments resting undisturbed upon the crystalline rocks of Liverpool Land.

Consistent with this fault, the data show a large depth to the basement in the eastern part of Jameson Land (4-6 km), and decreasing depths to the west. Surprisingly, it is difficult to detect the western fault boundary between the Jameson Land sediments and the crystalline rocks to the north of Scoresby Sund, except in a small area where mineralisation of the fault has taken place.

Magnetic measurements were also carried out between $74^{\circ} 15^{\prime}$ and $74^{\circ} 45^{\prime} \mathrm{N}$ for the purpose of comparing Jameson Land with Wollaston Forland where details of the tectonism are well known (Vischer, 1943).

\section{Low ground clearance flights}

Low ground clearance flights were carried out as a reconnaissance survey. An attempt was made to keep a constant ground clearance of 300 feet during the survey, and the flight tracks, following the fjords, valleys and other features, consequently deviated from a normal grid.

Magnetic data from flights of this type show several strong anomalies up to about 3500 gammas. These strong anomalies are clearly grouped. Two of these groups are connected with the Gletscherland migmatite complex at $72^{\circ} 45^{\prime} \mathrm{N}$ (Haller, 1955), and the basement series in the Pasterze Gletscher area at $74^{\circ} 45^{\prime} \mathrm{N}$ (Mittelholzer, 1941; Leedal, 1952), both complexes being probably of Precambrian age (N. Henriksen, perso- 
nal communication). These two areas were covered systematically, with $2.5 \mathrm{~km}$ line spacing, in order to produce aeromagnetic maps. An interesting anomaly (1200 gammas) in the nunatak zone just west of Shackletons Bjerg $\left(72^{\circ} 50^{\prime} \mathrm{N}\right)$, probably associated with metamorphosed sediments, was delineated. A detailed survey with 1-1.5 km line spacing was undertaken over an approximately $30 \mathrm{~km}$ wide section along the western, slightly mineralised, fault boundary between the post-Caledonian sediments and the crystalline complex to the north of Scoresby Sund.

\section{Ground work}

Only the Pasterze Gletscher area was visited this year. The rocks causing the anomalies were found to be highly metamorphic gneisses with a general, but economically uninteresting, magnetite enrichment.

\section{References}

Haller, J. 1955: Der »Zentrale Metamorphe Komplex« von NE-Grönland Teil I. Die geologische Karte von Suess Land, Gletscher Land und Goodenoughs Land. Meddr Grønland 73,3, 174 pp.

Leedal, G. P. 1952: The crystalline rocks of East Greenland between latitudes $74^{\circ} 30^{\prime}$ and $75^{\circ}$ N. Meddr Grønland 142,6, 80 pp.

Mittelholzer, A. E. 1941: Die Kristallingebiete von Clavering- $\emptyset$ und Payer Land (Ostgrönland). Meddr Gronland 114,8, 42 pp.

Vischer, A. 1943: Die postdevonische Tektonik von Ostgrönland zwischen $74^{\circ}$ und $75^{\circ} \mathrm{N}$. $\mathrm{Br}$, Kuhn $\varnothing$, Wollaston Forland, Clavering $\varnothing$ und angrenzende Gebiete. Vorläufiger Bericht über die Untersuchungen im Jahre 1938/39. Meddr Grфnland 133,1, 194 pp.

\section{Photo-reconnaissance of the Blosseville Kyst between Steward $\varnothing$ and S $\varnothing$ kongens Bugt, central East Greenland}

\section{Margrethe Watt}

The basalt area between Steward $\varnothing$ and Kap Dalton, and the inland region south of Kap Dalton, is one of the least known parts of central East Greenland. The following remarks are a result of a one day photo-reconnaissance flight over the area, made with the object of providing sufficient photographic material to show the most important tectonic features (fig. 21). No samples were collected.

From the air the basalts have the same general appearance as described from the 